\section{SCHOLARS: Journal of Arts \& Humanities}

[Peer-Reviewed, Open Access Scholarly Publication] Indexed in NepJOL; JPPS Star-Ranked Journal

Print ISSN: 2773-7829; e-ISSN: 2773-7837

eJournal Site: www.cdetu.edu.np/ejournal/
Central Department of English

Tribhuvan University

Kirtipur, Kathmandu, Nepal

URL: www.cdetu.edu.np

Theoretical/Critical Essay Article

\title{
Masculinity in Numafung, a Film Directed by Nabin Subba
}

\author{
Asmita Bista \\ Department of English, Mahendra Multiple Campus, Dharan, Nepal
}

Article History: Submitted 5 June 2021; Revised 8 July 2021; Accepted 5 August 2021

Corresponding Author: Asmita Bista,Email: asmitabista15@gmail.com

DOI: https://doi.org/10.3126/sjah.v3i2.39422

Copyright 2021 () The Author(s). The work is licensed under a Creative Commons Attribution 4.0 International License (CC BY 4.0).

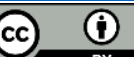

\begin{abstract}
The prevailing gender practices in the Limbu culture promote asymmetrical power relations not only between males and females but also between dominant males and subordinated males. This practice is portrayed in the feature film Numafung by Nabin Subba. Thus, the paper aims to investigate how the practice of hegemonic masculinity has affected the life of individuals, both males and females in Limbu community in the film. It scrutinizes what sort of problems do the conventional masculine roles bring in the characters' lives. This paper also intends to assess the reasons that force the males to perform the conventional gender roles. To analyze the text, $R$. W. Connell's and Michael Kimmel's idea of masculinity theory has been used as an approach. These theorists propose that masculinity is a constructed entity that is achieved through constant performance: a series of cues observed, internalized and repeated over time.

Illuminating the gender practices in the Limbu culture, Numafung unfolds the cultural dynamics of the Limbu society in the light of hegemonic masculinities. The paper concludes that cultural practices such as 'sunauli-rupauli,' 'mangena' and 'jari' keep their hegemonic masculinity intact. The paper further concludes that the male characters of Numafung embrace hegemonic masculinity because gender is a socio-cultural construction; being part of that society, one hardly can escape from the socially enforced gender roles.
\end{abstract}

Keywords: Gender roles, Limbu community, femininity, masculinity

\section{Introduction}

With deeply inside an ethnic culture and tradition, Numafung (2001), the first full feature film on the Limbu culture directed by Nabin Subba, appears as a milestone in the history of Nepali cinema. The film manifests itself as an innovative indigenous film by being experimental in nature, and separating itself from the conventional trend of other Nepali films that deal with the subjects such as sex, violence and humor. In fact, this film is a well-researched ethnographic document that reflects the real Nepal through the portrayal of a minute detail of the Limbu community, their lifestyle, and cultural 
practices. Consequently, this film gets an international acclaim as it received the 'Public Choice Award' in the Vesoul Film Festival, France (2003), the 'Runner-up Best Film' award in the Bangladesh International Film Festival (2003) and is shown as the "official selection" at international film festivals in Japan, Singapore, the Netherlands, USA, Austria and Czechia. Above all, depicting the cultural practices of the Limbu community, the film unravels the status of male-female bond in the Limbu community that instigates the researcher to select this film for research through the perspective of masculinity.

\section{Review of Literature}

Nabin Subba directed film Numafung has been under constant scrutiny by the film critics since its release in 2001. Since the film addresses a different subject than that of the mainstream Nepali cinema, the film critics enthusiastically express their reviews and comments on the film. Martin Gaenszle praises the film for bringing the culture of the Limbu community in the limelight. In Gaenszle's view, in this film, Subba brings the new ethnic awareness and pride that flourished in the post-1990 Nepal. Consequently, the film proves one of the most successful ethnic films not only in financial terms, but also in terms of artistic esteem (77). For Gaenszle, the film is a 'masterpiece,' which like no other films, has succeeded in revealing an ethnic culture and tradition. He views that the most salient feature of the film is its representation of Limbu ethnic culture as a whole. It is done in colorful, sensitive and empathic manner, which at the same time gives a vivid description with almost ethnographic quality.

Naresh Newar's view resembles with that of Gaenszle's as he praises the film for portraying a realistic image of cultural practices of the Limbu community. He argues that the film unravels the richness and affectionate qualities of an indigenous tradition. In doing so, the film exposes the culture of the Limbu of far-eastern Nepal. He claims that this film proves to be very useful to the audience to know about the Limbu community and their culture as the film depicts these elements in details. In Newar's view, the use of innovative subject puts "a purely Nepali element" in the film (8). He underscores that bestowing ethnic flavor and deviating from the trend of Nepali film making, this particular film can put the nation on the international film map.

Seira Tamang examines that Subbas's expertise in presenting the novice theme and setting make the film distinctive among other films in the country. In Tamang's perception, the film succeeds to make a distinguished place in Nepali film industry by "setting the movie within Limbu culture and community (one of the non-Indo Aryan groups of Nepal)" (par. 1). She observes that the film has minutely depicted every detail of the Limbu culture. Tamang points out that the film exposes some of the genuine issues of the Limbu community. Further, she underscores the matter of patriarchy within the framework of the Limbu culture that promotes gender inequality. In the same way, Alok Tumbahangphey appraises Subba's proficiency in making a neglected topic a big hit in the film. Tumbahangphey views that the film is a well-researched ethnographic document of the changing ways and lives of the rural Limbu people. He further points out that in this film every activity of the character reflects the Limbu culture. He emphasizes that either presenting each detail of their meals or in the scenes of grandmothers weaving on traditional handlooms or in the easy, unfettered interaction of young men and women in village markets, the film reproduces Limbu culture (par. 10). These critics have analyzed the film meticulously. However, they have left the scope for the researchers to analyze the film from the perspective of masculinity that has been discussed in the following section of this paper.

\section{The Concept of Masculinity}


The concept of masculinity has changed over time. However, in most societies, the term 'masculinity' is mainly linked to hegemonic/traditional masculinity that creates the male's image as provider, achiever, protector and oppressor. R. W. Connell and James W. Messerschmidt argue that the term 'hegemonic masculinity' "embodied the currently most honored way of being a man" (832). In fact, the term "hegemonic masculinity' is coined to acclaim the males' superiority as it "refers to the most dominant and most socially prized form of masculinity available to men" (McVittie et al. 121).

Connell mentions that "Hegemonic masculinity can be defined as the configuration of gender practice that embodies the currently accepted answer to the problem of the legitimacy of patriarchy, which guarantees (or is taken to guarantee) the dominant position of men and the subordination of women" (508). In Connell's perception, the male who practices hegemonic masculinity secures a powerful status in the society. So, males aim to achieve hegemonic masculinity. Moreover, the social institutions such as school, church and the like also focus on the development of hegemonic masculinity.

In most societies, hegemonic masculinity refers to the exalted form of masculinity; therefore, men try to be "more masculine' through exhibiting physical strength, self-control, and power over others" (Kimmel Manhood 218). Kimmel underscores that the characteristics associated with hegemonic masculinity include strength, competitiveness, assertiveness, confidence and independence. Cliff Cheng's views resemble to that of Kimmel's as he claims that "hegemonic masculinity is broadly characterized by "domination, aggressiveness, competitiveness, athletic prowess, stoicism and control" (298). These characteristics are considered hegemonic because they are accepted and reinforced by social norms, customs and behaviors. Vikki Krane argues that "Hegemonic customs and behaviors are so widely visible that they are rarely questioned, rather they are accepted as 'natural'. Males who act contrary to hegemonic masculinity or females who counter hegemonic femininity face discrimination and social exclusion" (3-4). These theorists notice that society prescribes masculine models that force man to become physically strong, to become competent leader, to become provider of the family, to become hardworking and successful person, and to find ways to achieve goals despite obstacles. Nevertheless, hegemonic masculinity does not necessarily reflect the lived identities of many, or indeed of any, individual men.

In Connell's and Kimmel's perception of hegemonic masculinity, most of the males fail to make a traditional masculine image because masculinity is a constructed entity rather than an innate human attribute. In Theorizing Masculinities, Kimmel assesses that the rules of manhood are constructed; therefore, only an insignificant fraction of men believe that they are "the most virulent repudiators of femininity and the most daring and aggressive" (138). Likewise, contesting the concept of monolithic masculinity, Connell claims that all men are not hegemonic; rather "It is institutionalized in the state; enforced by violence, intimidation and ridicule in the lives of straight men" (Masculinities 241). These theorists argue that men construct their masculine image by properly performing in line with the socially prescribed script. Following the same line of argument, this article evaluates the characters' gender roles in Subba's film Numafung.

\section{Gender and Numafung}

The Subba-directed Numafung portrays the characters at their performance of the stereotyped gender roles. Set in the hilly region of eastern Nepal, Kaziman Kandangwawritten Limbu film narrates the story of the Limbu community. Portraying the minute details of the lifestyle of this community, the film unravels that the Limbu people recurrently perform the socially imposed gender roles. Their gender behaviors have been 
presented in the different shots and sequences, which have been taken in the Limbu villages, where Numa, the central character of the film, spends the prime times of her life. The camera pans through Numas's house, her husbands' houses and the nearby villages. The main plot of the film revolves around Numa. The happenings of Numa's life come to the viewer through the eyes of her younger sister. Right from the first frame of the film, the viewers receive the characters' activities from her perspectives. She finds the behaviors of the males questionable. In fact, the entire range of gender issues such as the position of male and female members in the family, males' attitude and behavior towards males and females, marriage and males' struggles while ascertaining masculinity have been presented through her perspective.

Produced by Cahhabilal Hangshrong, Saraswati Limbu Hangshorng, the film presents the male characters in their conventional masculine roles. In the scene of Numa's marriage ceremony, the audience can clearly notice the male characters' efforts to ascertain masculinity. Since that society prescribes the roles of provider, protector, authoritative, strong and determined person to the males, performing the role of a provider and the family-head, Numa's father takes the decision of her life. He fixes her marriage despite her disagreement. Connell clarifies that when males get the role of a 'provider' they also get a "dividend from patriarchy in terms of honor, prestige and the right to command" (Masculinities 82). Moreover, he negotiates over the money and gold proposed in sunauli-rupauli (a custom of offering cash, gold, liquor and meat, from the groom's side to the bride's family) without taking Numa's consent.

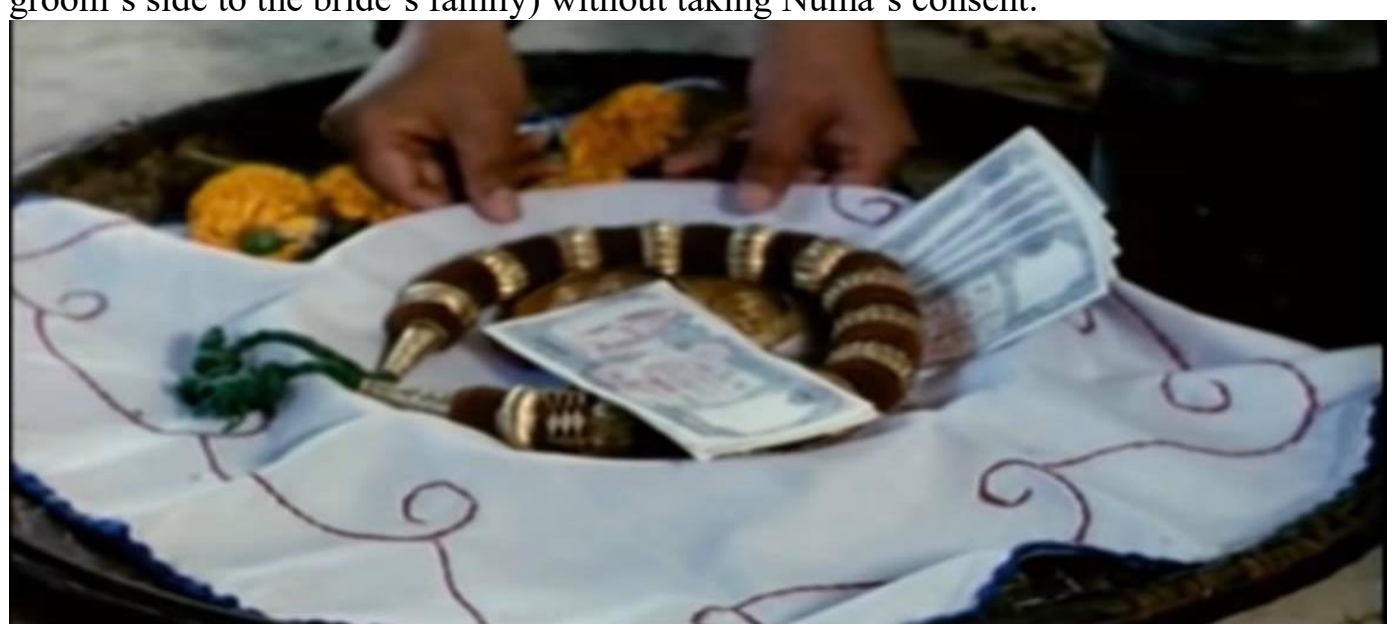

Fig. 1. Sunauli-rupauli presented by Ojhahang's/groom's side

Source: Author's screenshot

In this close-up shot, the audience can notice a naanglo 'wickerwork tray' with money and gold ornaments. In the Limbu community, there is a ritual called sunauli-rupauli, which makes boy's father/family to make a deal with girl's father/family. Making a deal successful becomes a matter of prestige for groom and his father. To persuades the bride's party, they fill the naanglo with demanded amount of money and gold. In fact, by making the naanglo acceptable, the groom's side wants to win the competition of claiming superiority over the bride's side. As Beverley Pennell elucidates that the society takes competitiveness as an essential masculine trait of hegemonic masculinity. So, the society motivates an individual to win the competition because for males 'winning' is a means of establishing self-worth (67). Therefore, to exhibit masculinity, they fulfil the demand of Numa's father by putting gold ornaments that worth ten tola (each tola is equal to 11.33 gram) and fifteen thousand rupees. 
In the film, the male characters even twist the cultural practice such as sunaulirupauli and use this ritual as a means of exploitation of female members while performing the role of an authoritative individual. Johan Alan Cohan claims: "Stereotyped roles lead to prejudices and customary practices that are premised on the inferiority of women, who in many cultures, still today are considered a part of a man's property" (181). In contrast to the Limbu culture, Kiranti women used to have better position in the society than the Hindu and Muslim society. But influenced by the mainstream Hindu culture, the Kirant society has gradually become patriarchal. Consequently, this society is also not free from the female domination (Limbu xxxii). So, the practice of patriarchy reflects in Numa's father's behavior. Using the practice of sunauli-rupauli, he claims his right over her.

In the film, while exhibiting masculinity, males not only twist, but also ruin and pollute the cultural practice. At one-point, Subba in an interview explains that the practice of sunauli-rupauli started as a way to protect the girls, who were married off across the river or mountains. The bride's parents kept the money for their married daughter's future security. In case, the husband remained abusive to his wife, she could come back her parental home and resume her life there. In a traditional Kiranti community, the money offered at the engagement time embodies the security of the girl married to a man but these days the money has become a prestige issue of both bride's and groom's father. Similarly, Chandra Kumar Serma reveals that these days the ritual of sunauli-rupauli has been ruined than that of the ancient Kirant cultural practice, in which the valuable ornaments that are received in sunauli-rupauli used to be kept as a security for bride, because these days "the Kirat society made daughter a means to gain, within the last two/three century" (22). In the film also, Numa's father twists the original significance of sunauli-rupauli. The film unravels that performing the role of hegemonic male, the males of Limbu community make, implement, define and twist the cultural practices of the Limbu community.

The Limbu males define the culture, rite, ritual and moral for their betterment. So Numa's father uses this ritual to acclaim his authority to Numa. Moreover, bargaining the amounts offered by the groom side in the second marriage of his widow daughter, he pollutes the beautiful practice of widow marriage. Likewise, portraying the second marriage ceremony of Numa, the film exposes that the Limbu culture itself promotes hegemonic masculinity by letting the father taking a decision of family members. In the film, endorsing the authority of Numa's father, all the family members force Numa to marry a person selected by her father. They do so in order to maintain the dignity of Numa's father because in that community, once the reet (offered amount from the groom's side to the bride's father) is accepted, the bride's father cannot take back the decision. Apart from that, the ritual of placing groom's knee and palm over the groom's knee and palm respectively signifies the male's superiority in a family hierarchy. In the film, while framing the details of Numa's marriage, Subba captures the shot in which people seem putting Girihang's knee and palm forcefully over Numa's knee and palm respectively. The shot discloses that this sort of ritual is developed to promote the male's dominance.

Through the character Ojahang, the film reveals that the males need to go through several hardships while maintaining the socially assigned gender roles. Since conventionally "masculinity has come to be associated with being bread-earner and the protector of the family" (Connell Masculinities 90), Ojhahang, Numa's husband, undergoes several difficulties, while performing the role of bread-earner of the family. Leaving a newly married wife at home, he migrates to a remote place to get the job of cutting logs and preparing planks. There, he gets badly injured as wood falls in his head. 
Consequently, he gets bedridden for many days. Connell rightly points out that the process of becoming masculine "follows many different paths and involves many tensions" (Connell Gender 6). The film exposes the problems that Ojhahang goes through while performing manliness as after the accident he never can live a healthy and normal life.

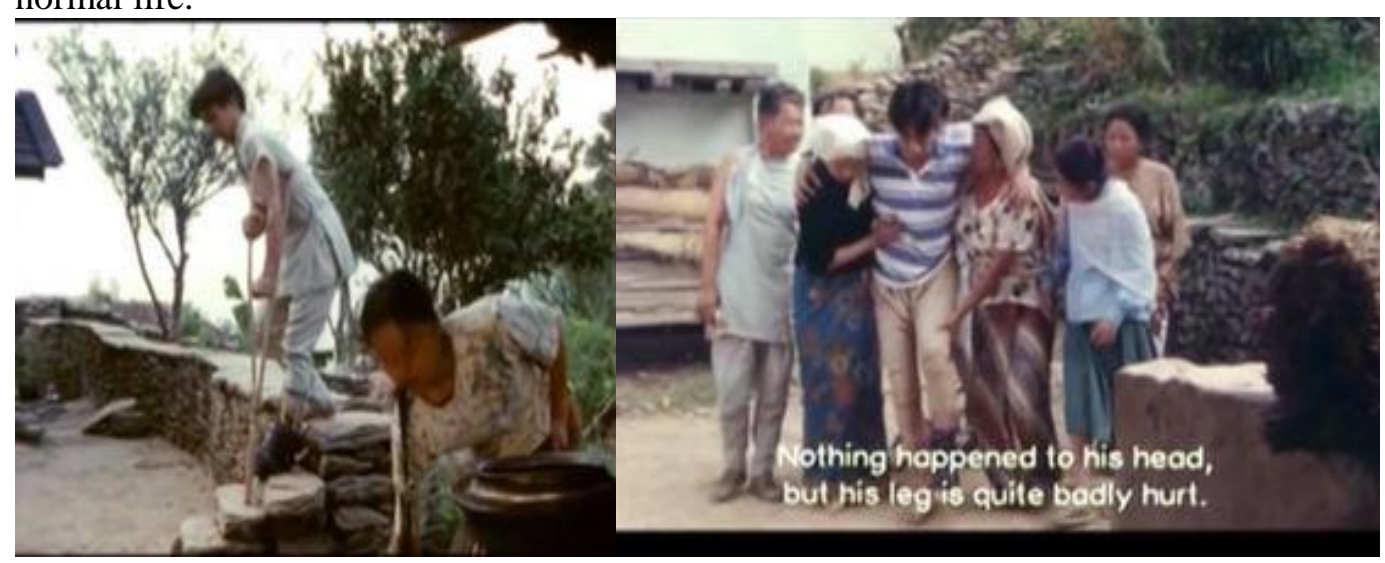

Fig. 2. Ojahhang's miserable condition caused by the accident

Source: author's screenshot

The above shots unfold Ojhahang's condition caused by the accident in the workplace. After the accident, he frequently gets severe headaches, feels giddiness and always needs somebody's aid for doing his daily activities. For several months, he walks with the support of crutch. Furthermore, the performance of masculinity reaches to its worst end when he dies due to his worst health condition that is resulted by the same accident.

In the film, most of the male characters acclaim their masculinity. In fact, putting their effort to make their masculinity visible, they do not leave even a single stone unturned. In the fair, Rikute stalks Numa and interferes on her activities. Similarly, boasting their masculinity Rikute's friends offer him to select one of the girls present in the fair as if they own them. Likewise, exhibiting their power, they assure to Rikute, "just choose one and we will fix her for you", moreover, they instigate him to "be bold". Besides these male characters, even Numa upholds the belief that the male should be daring. So, involving in the conversation, Numa challenges him to visit her house to ask her hand. Through Numa's challenge to Rikute, the film discloses that the males should be ever ready to pass the test of masculinity. As McVittie et al. claim that "masculinity is treated as synonymous with an identity that is broadly considered to be macho, assertive, aggressive, courageous, almost invulnerable to threats and problems, and stoic in the face of adversity" (122). Likewise, the elopement of Numa with Rikute accentuates that performing the role of Numa's rescuer/protector, he ascertains masculinity with a full bang.

Standing a step ahead to Rikute and his friends, Girihang appears as an archetype of masculinity. Having a strong body and quarrelsome personality, Girihang forms a masculine image of him. As Thomas Oates and Meenakshi Gigi Durham reveal: "the hyper-developed male body served as the embodiment of physical and cultural power" (301). In Oats and Durham's perception, "strong male body served as a means for hegemonic power to be maintained" (301). So, in the film, the camera recurrently focuses on Girihang's tall and heavy body (as in Nepali society the male having tall height and heavy body is taken as a strong person). Focused on his might, the camera also captures the shots in which GIrihang seems to go for hunting, displaying his power against his rivals and carrying weapons. His deeds confirm that masculinity "is a process through which various forms of power are reproduced and power becomes indelibly 
inscribed onto everyday life" (Kimmel 30). Additionally, going for horse-riding, he makes the sturdy built of his body visible as in Kimmel's perception, the male body itself would signify masculinity. Actually, Girihang uses all the possible ways to acclaim his manliness.

Practicing hegemonic masculinity, Girihang enjoys full of agency and will. He exercises his authority to his wife Numa as well as to other males, mainly his aids and followers, who belong to the lower class, affirming that "Hegemonic masculinity symbolizes and enacts power over other masculine identities as well as over women" (McVittie et al 122). Girihang seems to give order to the males who are from the lowerclass. Moreover, insulting these males, he acclaims his superiority as he declares: "If you can pay the due penalty, go ahead and take your sister-in-law. She used to be full of juice, but she's all dried up now." Girihang knows that because of their poverty, they are unable to pay jari 'due penalty'. So, offering them to become his jara 'adulterer,' he affronts them. Similarly, admitting that Numa has become worthless for him, he makes it clear that they can have only those things which are rejected by him

Framing the scene of the weekly Hat Bazaar, the film unravels that these places are significant not only for the local/Limbu's social activities such as dance, regional trade, courtship and elopement but also for male boasting, particularly by involving in fighting and having alcohol. There, they forcefully drag the desired maidens to make their wives. The film reveals that the males use such fairs and carnivals as a place of exhibiting masculinity. In order to display their strength and supremacy, they consume alcohol, demonstrate their weapons, and insult each other.
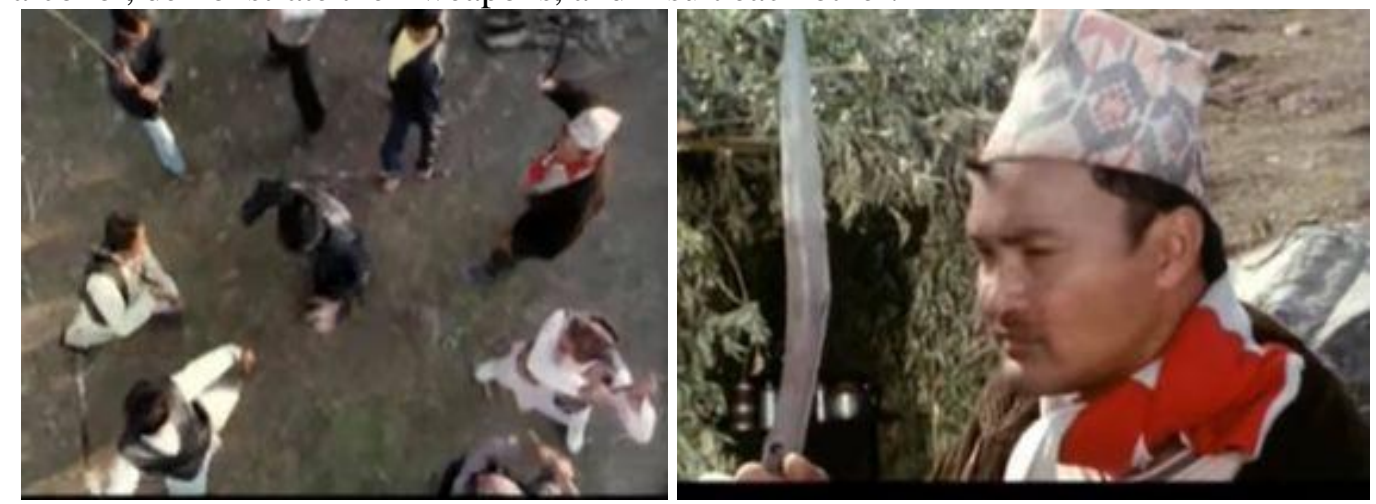

Fig. 3. Girihang, surrounded by his enemies, a man preparing to behead Girihang Source: author's screenshot These shots capture the fighting between Grihang and the boys from Yangnam village. The shot discloses that Girihang's enemies almost behead him but they pause when Numa begs them for their forgiveness. He takes her effort of saving his life as an insult to his masculinity because hegemonic masculinity actions "include refusal to acknowledge weakness or to be overcome by adverse events, while discouraging other behaviors such as the expression of emotions or the need to seek the help of others" (McVittie 122). Likewise, in that society, a person gets the label of emasculate if he is helped/rescued by women. Thus, he kicks her. Then, he challenges them saying that "if you are a real man, come and stab me, now. Why are you running away? Are you scared?" By reacting there violently, he tries to mend his masculine image that he assumes to be destroyed by receiving Numa's help unwantedly. As Connell and Messerschmidt claim, "The concept of hegemonic masculinity is based on practice that permits men's collective dominance over women to continue, it is not surprising that in some contexts, hegemonic masculinity actually does refer to men's engaging in toxic practices-including physical violence-that stabilize gender dominance in a particular 
setting" (840). Constructing the image of an unyielding, ungenerous gender ideal, Girihang follows the tradition of hegemonic masculinity.

When Girihang proposes to go to the fair to his followers, they warn him that there's going to be trouble this time. They report him: "Remember Ranbir from Yangham village, who you beat once? He was trying to create a scene at the last fair." Then, inspired by revenge motive that patriarchy installs in the male body, Girihang declares that "He was acting up because I wasn't there. This time I'm also going, and I'll teach him a lesson, break a limb or two." The conversation of Girihang and his followers reveals that Girihang displays manliness by involving in fighting the males from nearby villages.

In the film, societal norms and values of Limbu community have been used to uphold as well as uplift the masculinity of Limbu males. Mangena 'holding head up/high' is one of the famous cultural practices of Limbu community, in the village of Numafung that is done to emphasize the male's dignity. In fact, this society promotes hegemonic masculinity, confirming that "hegemonic masculinity constitutes the most socially valued form of masculinity to which individual men can aspire" (McVittie et al. 122). Therefore, masculinity is manifested in many of their everyday actions and mangena is one of them. In the Limbu culture, mangena is used as an essential part of their day-to-day negotiations. In the Limbu community,

mangena ritual is performed every six months in the beginning of summer and winter season. If two times of the year is not possible, it is suggested that it should be held at least once a year. The primary purpose of this rite is that the person may not feel any inferiority complex in his/her business/profession or even in the daily activity. However, in the modern time maangenaa is performed to protect oneself from accidents, disputes, fighting, wars, and jealousy and to succeed in the desired attempts. (Tumbahang71)

Nevertheless, in the film, mangena is performed by a man to hoist the self-respect of another man. Actually, in this social milieu, this ritual is used to ascertain manhood. So, after a fight with a village neighbor Dandaghare, Girihang apologizes by doing mangena/sir uthaaune. For that, he presents a bottle of wine and a cock to Dadaghare, whom he had insulted some days ago for no reason but he never seems doing mangena to Numa whom he regularly insults.

Most of the male characters display courage and strength, holding the image of hegemonic masculinity. Since, in the society, "Men, oriented to the public sphere, are understood to be active, strong, independent, dominant, powerful, and aggressive" (Adam and Coltrane 232), so, in order to exhibit his bravery and power, Girihang recurringly involves in violence. He thrashes his neighbor despite of the neighbor's innocence. After that incident, when Numa suggests him, "you should not have raised your fists against him", he arrogantly replies: "you do not know about this village. These villagers must be treated firmly to be kept under control." Actually, he seeks excuses to initiate fight with people. While returning home with Numa, when he notices that Sanughare is laughing while chaffing the crops, assuming Sanughare's laugh as an insult to him, he gets angry and summonses Sanughare for fighting. Actually, Girihang decides to teach him a lesson; likewise, defeating Sanughare, he wants to boast his poise to his wife. Therefore, he constantly insists to accept his challenge even though Sanaghare shows his reluctance for fighting. 

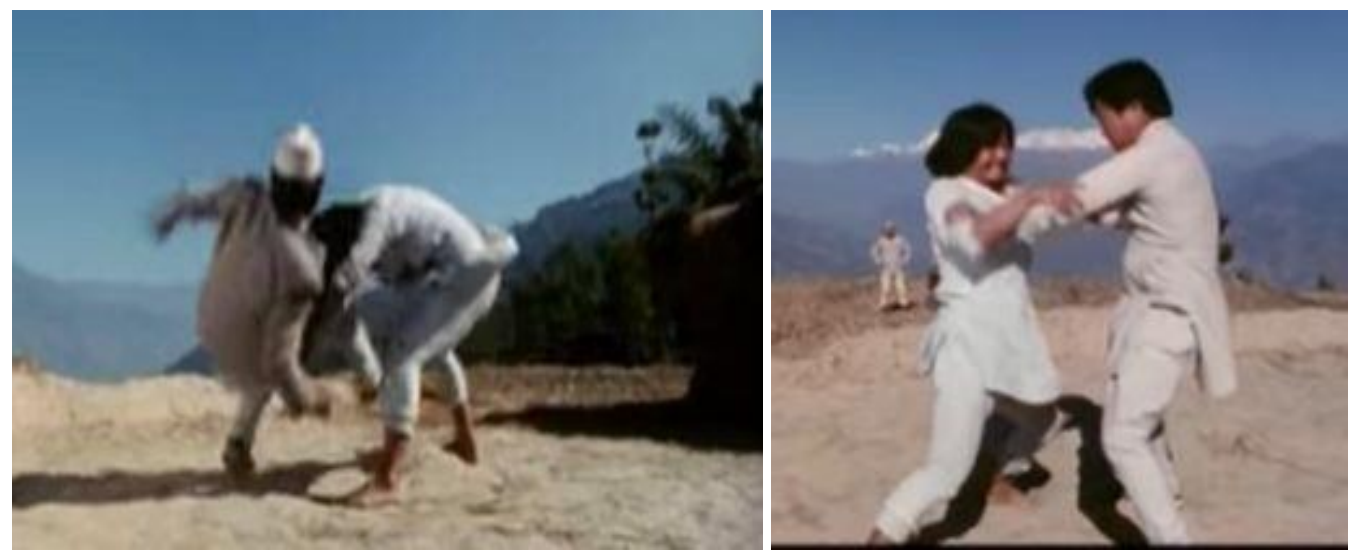

Fig. 4. Girihang and Sanaghare are fighting violently

Source: author's screenshot

In these shots, both of the males seem to involve in fighting ferociously as they are eager to prove their strength over another. When Sanaghare beats Girihang in fighting,

Girihang does not accept his defeat. Rather, he makes an excuse that he cannot win due to his improper dress.

Since hegemonic masculinity imparts the husband's superiority over his wife, this practice resulted in victimization of Numa by Girihang. Likewise, maintaining the image of a dominant husband, he insults her publicly. Connell reveals that men actively struggle for dominance and this active struggle for dominance is actually fundamental in redefining what a normal male identity should be (Gender 28). By exercising his authority over Numa, he creates a masculine identity for him. Maintaining the masculine image, he even beats her for no reason.

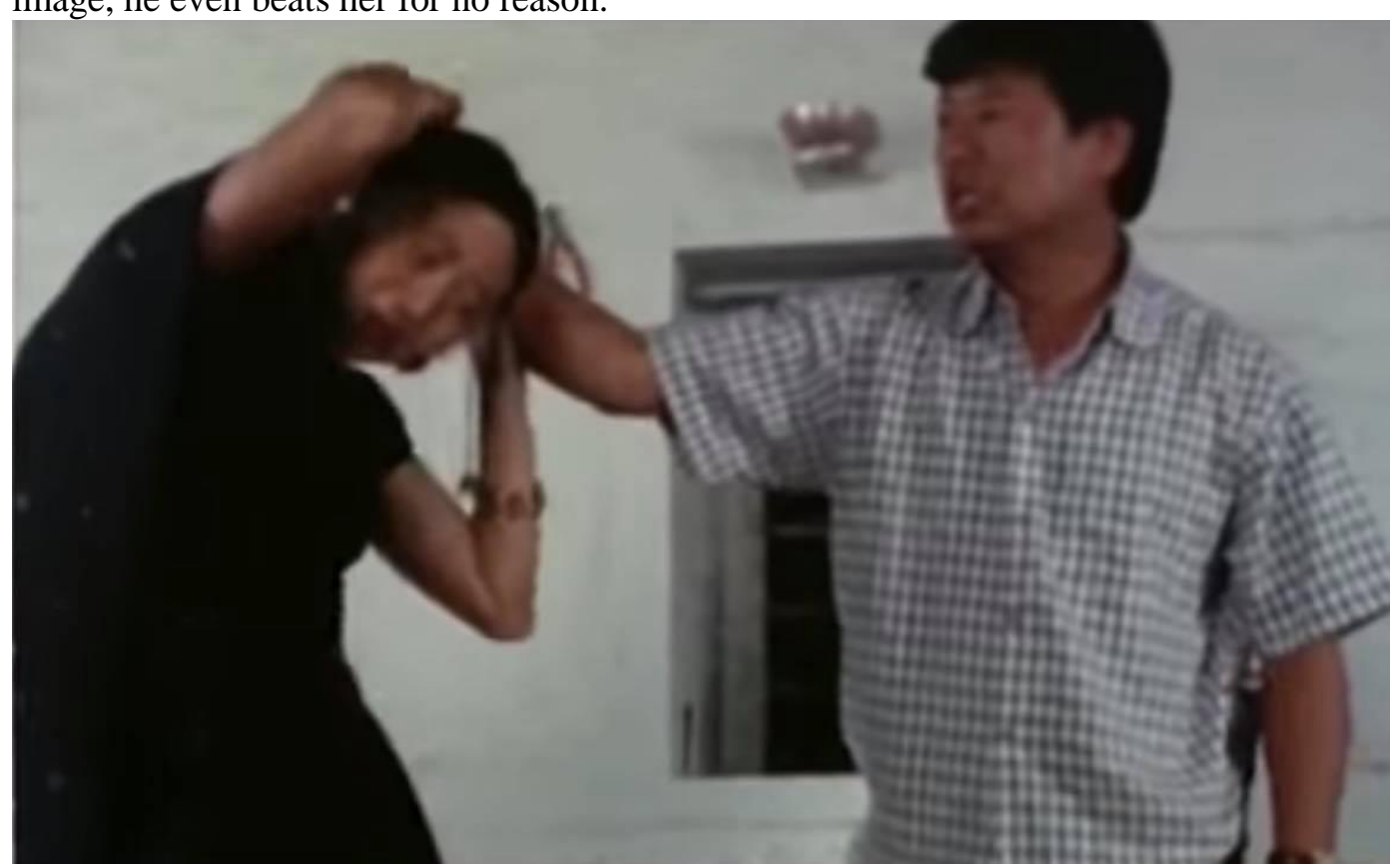

Fig. 5. Girihang pulling Numa's hair angrily

Source: author's screenshot

In this close-up shot, the audience can notice Girihang's aggression, rage and ruthlessness. He pulls her hair while she is having meal. In that society, it is a common practice to use violence against one's wife because "being a patriarchal society Kirant society is not free from the female domination. Mundhum presents the female as the 
creator of human, initiator culture, and Goddess of inspiration, love, and success Therefore, Mundhumi era was appreciable for female right as "there was not female domination and exploitation" (Limbu xxxii). However, these days, "treating female as males' property has become a common practice in Limbu culture" (Limbu xxxii). Consequently, Girihang acclaims his ownership on Numa and uses her as a tool to satisfy his male ego. Moreover, he even sexually abuses her. As Hoorocks claims that sexual abuse is "undoubtedly part of patriarchy's humiliation and oppression of women" (139). Molding in the role of hegemonic masculinity, Girihang appears as a ruthless husband.

Subba reveals that the cultural practice of jar system in Limbu community enhances the male's authority because both of the parties i.e., jar and the husband, get opportunity to exhibit their masculinity. By paying jari, jar gets opportunity to brag. Likewise, by providing jari to the ex-husband, the ex-husband's manliness gets uplifted. In the film, when Numa elopes with Rikute, Girihang arrives in Numa's house to claim jari. Actually, Girihang should claim jari from Rikute but he disappears with Numa. Girihang asks for jari to Numa's father. Moreover, he pressurizes Numa's father for the double payment of sunauli-rupauli's amount in the form of jari even though he knows that his demand resulted to homelessness of Numa's family. On top of that, even the society endorses Girihang's ruthlessness. The leaders of that community force Numa's father for the double payment of sunauli-rupauli amount. Rotundo rightly claims that manhood is "a human invention, manhood is learned, used, reinforced, and reshaped by individuals in the course of life" (7). Observing the cultural practices of his surroundings, Girihang acts pitilessly to his ex-father-in -law. The villagers, who give verdict in favor of Girihang, are the males who not only make the law, but also implement it and even twist it in order to resurrect the masculinity of Girihang that is threatened by Numa's elopement. As a result, Numa's father pays jari to him. In this case, he appears powerless and helpless person. In order to arrange money, he has to sell his property. Ultimately, along with his family, he has to migrate from the village.

The condition of Numa's father unravels that hegemonic form of identity is not easily performed by all men in every condition. Girihang's situation exposes that masculinity is constructed through prescribed and idealized set of norms; it does not "correspond closely to the lives of any actual men" (Connell and Messerschmidt 838). After facing the consequences caused by Numa's elopement, he no longer carries forward the burden of hegemonic masculinity. On the one hand, he cannot protest against the wrong practice of jari system even though he finds it wrong, and on the other hand, being penniless and homeless, he fails to befit in the role of a 'provider' and 'protector' of his family. Portraying his condition, the film reflects Connell's and Messerschmidt's view, "Masculinity is not a fixed entity embedded in the body or personality traits of individuals. Masculinities are configurations of practice that are accomplished in social action and, therefore, can differ according to the gender relations in a particular social setting" (836). Likewise, the film upholds the fact that hegemonic masculinity is an impractical, unreachable (for many males), and harmful.

\section{Conclusion}

This paper has demonstrated that Subba-directed film Numafung reflects the lifestyle of the Limbu people. The film discloses that the people of this community involve in cultural practices such as jari, Mangena, and sunauli-rupauli. These cultural practices of the Limbu community endorse hegemonic masculinity by concentrating social dividends to the powerful males. Due to the gender biased cultural practices, the Limbu males dominate and exploit the females. Similarly, the Limbu males who belong to the higher social status subjugate the subordinated males. Since the Limbu community 
assigns masculine roles to the males, they recurrently appear in the identity of authoritative, strong, and brave individual.

While ascertaining manhood through cultural practices such as jari and sunaulirupauli, the male characters rebuke, insult and ridicule the subordinated males. Equally, they harass, exploit and torture females. Guided by patriarchal mind-set that groomed more in the Limbu culture, fathers impose unwanted marriages to their daughter. Likewise, they misuse the custom such as sunauli-rupauli for acclaiming their authority over their daughters. Following the socially written script, the male characters try to act masculinely. They appear as quarrelsome, treacherous, cruel individual while exercising their strength and authority. They involve in fighting, insult the neighbors and friends, and behave rudely and aggressively. Apart from that, they consume alcohol, abuse the female members of the family. Hence, through the male characters, the film unravels that hegemonic masculinity is harmful to all. In the same way, presenting the incidents such as Numa's father's feeble and hopeless condition, his failure to maintain the role of 'provider,' 'protector' of the family, the film exposes that hegemonic masculinity is unreachable to many males.

\section{Works Cited}

Adams, Michele, and Scott Coltrane. "Boys and men in families: Domestic Production of Gender Power and Privilege." Handbook of Studies on Men and Masculinities. Edited by Michael S. Kimmel, Jeff Hearn and R. W. Connell, Sage Publication, 2005, pp. 230-248.

Cheng, Cliff. "Marginalized Masculinities and Hegemonic Masculinities: An Introduction." Journal of Men's Studies, vol. 7, no. 3, 1999, pp. 295-315.

Cohan, Johan Alan. "Honor Killings and the Cultural Defense." California Western International Law Journal, vol. 40, no. 2, Spring 2010, pp. 178-249.

Connell, R.W. and James W. Messersehmidt. "Hegemonic Masculinity: Rethinking the Concept." Gender and Society, vol. 9, no. 6, 2005, pp. 829-859.

Connell, R.W. "Globalization, Imperialism and Masculinities." Handbook of Studies on Men and Masculinities. Edited by Michael S. Kimmel, Jeff Hearn and R.W. Connell, Sage Publication, 2004, pp. 71-89.

---. Gender in World Perspective. Polity Press, 2009.

---. "Masculinities, Relations Among." Men and Masculinities: A Social, Cultural, and Historical Encyclopedia. Edited by Michael Kimmel and Amy Aronson. ABCCLIO, vol. I, 2004, pp. 507-510

---. Masculinities. U of California Press, 2005.

Gaenszle, Martin. "Numafung: Image of Limbu Culture in Ethnic Cinema." Political Change and Public Culture in Post-1990 Nepal. Edited by Michael Hutt and Pratyoush Onta, Cambridge UP, 2017, pp. 77-96.

Horrocks, Roger. Masculinity in Crisis: Myths, Fantasies and Realities. St. Martin Press. 1994.

Interview: Nabin Subba. Sansar Media, 13 April 2004, https://sansarmedia.blogspot.com/1999/01/interview-nabin-subba.html.

Karne, Vikki. "Fair Treatment and Discrimination in Sport" Encyclopedia of Applied Psychology. vol. 2, 2004, pp. 1-10

Kimmel, Michael. Manhood in America: A Cultural History. Free Press, 1996.

---. "Masculinity as Homophobia: Fear, Shame, and Silence in the Construction of Gender Identity." Theorizing Masculinities. Edited by Harry Brod and Michael Kaufman, Sage Publications, 1994, pp. 119-141

---. "Invisible masculinity." Society, vol. 30, 1993, pp. 28-35 
Limbu, M.K. "Subversion of Hierarchy between Male and Female in Satydhama Muchulk." 2012, http://107.170.122.150:8080/xmlui/bitstream/handle/123456789/992/Thesis.pdf? sequence $=2 \&$ is Allowed $=y$.

McVittie, Chris et al. "Masculinities and Health: Whose Identities, Whose Constructions?" The Psychology of Gender and Health: Conceptual and Applied Global Concerns. Edited by Pilar Sanchez Lopez and Rosa M. Limina, Academic Press, 2017, pp. 119-141.

Newar, Naresh. "Kollywood: It's not the Same Old Song-and-Dance Anymore in Nepal Industry." Nepali Times, vol. 156, 2003, p. 8.

Oates, Thomas and Meenakshi Gigi Durham. "The Mismeasure of Masculinity: The Male Body, 'Race', and Power in the Enumerative Discourses of the NFL Draft." Patterns of Prejudice, vol. 38, 2004, pp. 301-320.

Pennell, Beverly. "Redeeming Masculinity at the End of the Second Millennium: Narrative Reconfigurations of Masculinity in Children's Fiction." Ways of Being Male. Edited by John. Stephens, Routledge, 2002, pp. 55-77.

Rotundo, E. Anthony. American Manhood: Transformations in Masculinity: From the Revolution to the Modern Era. Basic Books, 1993.

Serma, Chandra Kumar. Kiratka Karma, Sanskar Bidhi. $2^{\text {nd }}$. ed, Daya Prasad Angbung, 2009.

Subba, Nabin, director. Numafung. Menchhyayem Pictures, 2001.

Tamang, Seira. "The Sweet Perfume of Numafung." Himal South Asian, 1 November 2002. https://www.himalmag.com/the-sweet-perfume-of-numafung/.

Tumbahangphey, Alok. “A Beautiful Flower.” Nepali Times, issue 93, May 2002, https://nepalitimes.com/news.php?id=6714.

Tumbahang, Mohan Kumar. "Cultural Specific Language in Kirat Yaakthung Mundhum." Dristikon: A Multidisciplinary Journal, vol. 9, no. 1, December 2019, pp. 63-74. 